Vol. 9 No. 1 April 2016

PSIBERNETIKA

\title{
PERAN GAYA KEPEMIMPINAN TRANSFORMASIONAL DAN \\ TRANSAKSIONAL TERHADAP KETERIKATAN KERJA (STUDI PADA \\ KARYAWAN UNIVERSITAS X)
}

\author{
Garvin Goei \\ Willy Budiman Winata
}

\begin{abstract}
The purpose of the study is to examine the role of transformational and transactional leadership to the employees' work engagement. Transformational leadership is defined as a leadership style that involves interaction between the leader and follower, and mutually enhance each other into higher degree of morality and motivation. Transactional leadership is defined as leadership style that occurs when the leader gives reward or discipline to the followers. Work engagement is defined as positive mental state, selffulfillment, and related to work that is characterized with vigor, dedication, and absorption. The research involves 105 employees that work in " $X$ " University in Western Jakarta, using convenient sampling technique. Regression analysis showed that perceived transformational and transactional leadership both gives significant role to the work engagement.
\end{abstract}

Keywords: transformational leadership, transactional leadership, work engagement, employee

\section{A. LATAR BELAKANG}

Seiring dengan berkembangnya paradigma psikologi positif yang dipelopori oleh Martin Seligman, tema-tema yang mengangkat sisi positif manusia pun menjadi semakin sering mendapat eksplorasi dari para ilmuwan, demikian juga pada bidang psikologi industri dan organisasi (Bakker, Schaufeli, Leiter, \& Taris; 2008). Salah satu variabel di antara tema yang membahas psikologi positif dalam latar industri dan organisasi adalah keterikatan kerja atau work engagement (Schaufeli, Bakker, dan Salanova; 2006).

Keterikatan kerja adalah keadaan positif dalam bekerja sehingga karyawan akan memenuhi tugas-tugas dalam pekerjaannya (Schaufelli \& Bakker dalam Bakker, Hakanen, Demerouti, Xanthopoulou; 2007). Keterikatan kerja membuat karyawan terlibat baik secara fisik, emosional, dan kognitif terhadap pekerjaannya (Bakker et al, 2007). Marciano (2009) menyebutkan bahwa keterikatan kerja yang dimiliki oleh seorang karyawan 
merupakan faktor yang sangat penting untuk meningkatkan performanya; upah yang tinggi kini bukan hal yang utama lagi bagi seorang karyawan, melainkan keterikatan seorang karyawan terhadap pekerjaannya dan juga perusahaan tempat dia bekerja.

Menurut Bakker \& Demerouti (dalam Sweetman dan Luthans, 2010), keterikatan kerja dipengaruhi oleh dua faktor, yaitu sumber daya pekerjaan dan tuntutan pekerjaan. Sumber daya pekerjaan merupakan sumber-sumber yang mampu meningkatkan prestasi, menyangga tuntutan pekerjaan, dan meningkatkan pertumbuhan serta perkembangan karyawan (Sweetman dan Luthans, 2010). Berarti, pekerjaan yang menimbulkan prestasi, pertumbuhan, serta perkembangan bagi karyawan dapat berpengaruh terhadap keterikatan kerja karyawan. Keterikatan kerja juga berkaitan secara positif dengan dukungan sosial dari atasan dan bawahan (Schaufeli dan Salanova, 2007). Dalam riset yang dilakukan oleh Koppula (2008), ditemukan bahwa gaya kepemimpinan transformasional berkorelasi dengan keterikatan kerja pada karyawan. Hal ini kemudian diperdalam lagi BabcockRoberson dan Strickland (2010) yang menemukan bahwa gaya kepemimpinan karismatik memiliki hubungan positif dengan keterikatan kerja.

Temuan-temuan maupun pembahasan-pembahasan tersebut memberikan dua pemahaman, yakni pekerjaan yang mendukung pertumbuhan serta perkembangan karyawan dapat memengaruhi keterikatan kerja karyawan dan hubungan antara atasanbawahan yang positif memiliki korelasi yang positif dengan keterikatan kerja. Hal ini memunculkan asumsi bahwa gaya kepemimpinan berperan dalam keterikatan kerja karyawan. Hasil riset sebelumnya menemukan bahwa gaya kepemimpinan transformasional (Koppula, 2008) dan karismatik (Babcock-Roberson dan Strickland, 2010) memiliki hubungan dengan keterikatan kerja karyawan. Gaya kepemimpinan karismatik sendiri sebenarnya merupakan salah satu komponen dari gaya kepemimpinan transformasional (Bass \& Riggio, 2006).

Di sisi lain, peneliti menemukan beberapa temuan gaya kepemimpinan dalam kaitannya dengan latar atau konteks bidang organisasi. Dalam penelitian yang dilakukan oleh Morrison, Jones, dan Fuller (1997); gaya kepemimpinan transformasional dan transaksional dapat diterapkan dalam bidang layanan kesehatan seperti perawat. Dalam latar militer, gaya kepemimpinan transformasional dan transaksional juga dapat digunakan oleh pemimpin dalam mengelola tim (Bass, Avolio, Jung, dan Berson; 2003). Dalam latar 
Vol. 9 No. 1 April 2016

PSIBERNETIKA

industri pendidikan, gaya kepemimpinan yang paling sering digunakan oleh kepala sekolah dalam berbagai tingkat pendidikan adalah gaya kepemimpinan transformasional, disusul dengan gaya kepemimpinan transaksional (Onorato, 2013). Karyawan dalam intansi pendidikan menilai bahwa pengaturan sumber daya karyawan merupakan keterampilan paling penting yang harus dimiliki oleh pemimpin dalam sebuah instansi pendidikan; salah satu keterampilan dalam pengaturan sumber daya karyawan ini adalah melibatkan karyawan untuk mengambil peran dalam mengambil keputusan penting (Kalargyrou, Pescosolido, dan Kalargiros; 2012).

Dalam konteks organisasi yang bergerak dalam jasa pendidikan, gaya kepemimpinan yang sering digunakan adalah transformasional dan transaksional (Onorato, 2013). Meskipun hasil riset sudah menunjukkan bahwa gaya kepemimpinan transformasional memiliki korelasi terhadap keterikatan kerja (Koppula, 2008), masih diperlukan riset yang lebih lanjut, yakni peran dari gaya kepemimpinan transformasional terhadap keterikatan kerja. Dalam konteks pendidikan, gaya kepemimpinan transaksional juga sering digunakan, di samping gaya kepemimpinan transformasional (Onorato, 2013), namun peneliti masih menemukan minimnya penelitian yang mengkaji tentang gaya kepemimpinan transaksional terhadap keterikatan kerja, khususnya dalam konteks organisasi yang bergerak dalam bidang pendidikan. Hal ini akhirnya menimbulkan keinginan bagi peneliti untuk melakukan penelitian mengenai peran dari gaya kepemimpinan transformasional dan transaksional terhadap keterikatan kerja.

\section{B. TUJUAN PENELITIAN}

Secara umum, tujuan penelitian ini adalah untuk mengetahui peran gaya kepemimpinan transformasional, gaya kepemimpinan transaksional, dan interaksi antara kedua gaya kepemimpinan tersebut terhadap keterikatan kerja pada karyawan yang bekerja di Universitas X. 


\section{TINJAUAN TEORI}

\section{Kepemimpinan}

Kepemimpinan adalah kualitas kepribadian dan latihan yang mengarah pada keberhasilan dalam membimbing dan mengontrol orang lain (Chaplin, 2006). Kepemimpinan menurut Sofyandi dan Garniwa (2007) adalah proses pengaruh sosial dalam hal pengaruh yang sengaja dijalankan oleh seseorang terhadap orang lain untuk menstruktur aktivitas-aktivitas serta hubungan-hubungan di dalam sebuah kelompok atau organisasi. Kepemimpinan berfungsi untuk memudahkan tercapainya sasaran kelompok. Berdasarkan penjelasan-penjelasan tersebut, dapat disimpulkan bahwa kepemimpinan merupakan kualitas-kualitas yang dimiliki oleh seorang pemimpin dalam menjalankan tugasnya sebagai pemimpin.

\section{Gaya Kepemimpinan Transformasional}

Gaya kepemimpinan transformasional adalah gaya kepemimpinan yang merangsang dan menginspirasi pengikutnya untuk mencapai hasil yang luar biasa dan dalam prosesnya juga mengembangkan kapasitas kepemimpinan mereka sendiri (Bass \& Riggio, 2006). Menurut Phipps dan Prieto (2011) mendefinisikan gaya kepemimpinan transformasional sebagai gaya kepemimpinan yang terjadi ketika pemimpin mengikutsertakan pengikut, memastikan bahwa kedua pihak terangkat ke taraf motivasi dan moralitas yang lebih tinggi sambil mengerjakan tujuan bersama. Landy dan Conte (2007) mendefinisikan gaya kepemimpinan transformasional sebagai interaksi antara pemimpin dan pengikut yang saling meningkatkan satu sama lain menuju tingkat moralitas dan motivasi yang lebih tinggi.

Bass dan Riggio (2006) menyatakan bahwa gaya kepemimpinan transformasional terdiri dari empat dimensi, yaitu (a) idealized influence atau pengaruh yang ideal atau karisma, (b) inspirational motivation atau motivasi inspiratif, (c) intellectual stimulation atau rangsangan intelektual, dan (d) individualized consideration atau pertimbangan individual. Idealized influence kemudian dipecah menjadi dua dimensi, yaitu (1) attributed charisma, dan (2) idealized influence behavior. Attributed charisma atau attributed idealized influence didefinisikan oleh Bass dan Riggio (2006) sebagai elemen-elemen yang diatribusikan oleh pengikut kepada pemimpinnya sebagai sosok yang dikagumi, dihargai, dan dipercayai. Idealized influence behavior atau idealized influence atau 
Vol. 9 No. 1 April 2016

PSIBERNETIKA

pengaruh yang ideal merupakan dimensi yang selanjutnya gaya kepemimpinan transformasional. Idealized influence ditunjukan dengan pemimpin yang menunjukkan keyakinan, menekankan rasa percaya, menghadapi isu-isu sulit, menekankan pentingnya komitmen dan tujuan, dan sadar terhadap konsekuensi etis dari keputusan mereka (Landy dan Conte, 2007). Bass dan Riggio (2006) menjelaskan bahwa idealized influence adalah perilaku yang membuat pemimpin dianggap sebagai panutan dari pengikutnya.

Inspirational motivation atau motivasi inspiratif ditunjukan dengan pemimpin mengartikulasikan pandangan yang menarik mengenai masa depan, menantang pengikut dengan standar yang tinggi, berbicara secara optimis dan antusias, serta menyediakan dukungan maupun makna terhadap kebutuhan-kebutuhan yang perlu diselesaikan (Landy dan Conte, 2007). Menurut Bass dan Riggio (2006), pemimpin yang memiliki karakteristik inspirational motivation bersikap dengan cara yang memotivasi dan menginspirasi orang-orang di sekitar mereka dengan menyediakan makna dan tantangan kepada pekerjaan pengikutnya, menampilkan antusiasme dan optimisme.

Intellectual stimulation atau rangsangan intelektual dicirikan dengan pemimpin mempertanyakan asumsi-asumsi, nilai-nilai, dan keyakinan-keyakinan lama; merangsang cara baru dalam mengerjakan sesuatu dan mendukung ekspresi dari ide serta penalaran (Landy dan Conte, 2007). Seorang pemimpin yang memiliki karakteristik intellectual stimulation mampu merangsang pengikutnya untuk berusaha inovatif dan kreatif dengan mempertanyakan asumsi-asumsi, membingkai ulang masalah, dan mendekati situasi lama dengan cara yang baru (Bass dan Riggio, 2006). Intellectual stimulation mendukung kreativitas. Individual consideration atau pertimbangan individual terlihat dari pemimpin menghadapi pengikutnya sebagai individu, mempertimbangkan kebutuhan-kebutuhan dan aspirasi-aspirasi individu, mendengar dengan perhatian, menasihati, membimbing, dan mengajar (Landy dan Conte, 2007). Bass dan Riggio (2006) menyatakan bahwa seorang pemimpin yang memiliki karakteristik individual consideration menaruh perhatian khusus kepada masing-masing individu pengikutnya untuk prestasi dan pertumbuhan dengan bertindak sebagai pembimbing atau mentor. 
Pemimpin dengan gaya kepemimpinan transformasional tidak memimpin secara otoriter, melainkan dengan menjadi rekan untuk mencapai tujuan bersama, saling berkontribusi, dan meningkatkan kapasitas performa satu sama lain (Modassir dan Singh, 2008). Goethals (2005) mengatakan bahwa gaya kepemimpinan transformasional menginspirasi identifikasi terhadap diri pemimpin dan pengikut sebagai manusia dengan ide-ide serta tujuan-tujuan mereka. Dari definisi-definisi dan penjelasan tersebut, dapat disimpulkan bahwa gaya kepemimpinan transformasional adalah gaya kepemimpinan dengan membawa pengikut-pengikutnya untuk ikut berkembang sekaligus mencapai tujuan bersama.

\section{Gaya Kepemimpinan Transaksional}

Gaya kepemimpinan transaksional adalah gaya kepemimpinan yang terjadi ketika pemimpin memberikan penghargaan atau mendisiplinkan pengikutnya, bergantung pada adekuasi performa pemimpin (Bass dan Riggio, 2006). Dimensi-dimensi dari gaya kepemimpinan transaksional adalah: (a) contingent reward, dan (b) active management by exception, dan (c) passive management by exception (Bass dan Riggio, 2006). Contingent reward adalah dimensi yang pertama dari gaya kepemimpinan transaksional, dengan cara pemimpin menjanjikan hadiah jika pengikutnya dapat mengerjakan tugas dengan memuaskan (Bass dan Riggio, 2006). Menurut Antonakis, Avolio, dan Sivasubramaniam (dalam Bass dan Riggio, 2006), contingent reward akan bersifat transaksional jika hadiah yang diberikan bersifat materi, seperti uang; sedangkan akan bersifat transformasional jika hadiah yang diberikan bersifat psikologis, seperti pujian. Active management by exception adalah gaya kepemimpinan di mana pemimpin secara aktif mengawasi penyimpanganpenyimpangan dari standar, kesalahan-kesalahan, dan kekeliruan-kekeliruan dalam tugastugas pengikutnya dan mengambil langkah korektif secepatnya (Bass dan Riggio, 2006). Pemimpin akan ikut mengawasi kinerja pengikutnya untuk mencegah terjadinya kesalahan. Passive management by exception adalah gaya kepemimpinan di mana pemimpin akan menunggu secara pasif munculnya penyimpangan-penyimpangan, kesalahan-kesalahan, dan kekeliruan-kekeliruan kemudian mengambil langkah korektif (Bass dan Riggio, 2006). Pemimpin akan diam saja dan bertindak ketika sudah terjadi kesalahan. 
Vol. 9 No. 1 April 2016

PSIBERNETIKA

\section{Keterikatan Kerja}

Keterikatan kerja atau work engagement didefinisikan sebagai keadaan pikiran yang positif, pemenuhan diri, dan berhubungan dengan pekerjaan yang dikarakteristikan dengan vigor, dedication, dan absorption (Schaufelli dan Bakker, 2003). Kahn (dalam Attridge, 2009) mendefinisikan keterikatan kerja sebagai rasa kerasan dari diri seseorang terhadap peran kerjanya. Keterikatan kerja berarti keterlibatan, komitmen, dan bergairah dengan pekerjaan (Attridge, 2009). Menurut Bakker, Schaufeli, Leiter, dan Taris (2008); keterikatan kerja ditandai dengan energi yang tinggi dan identifikasi yang tinggi terhadap pekerjaannya. Schaufeli dan Bakker (2003) menyatakan bahwa keterikatan kerja dapat diasumsikan sebagai lawan dari burnout.

Keterikatan kerja yang tinggi ditemukan pada karyawan-karyawan dengan kesejahteraan psikologis yang tinggi, kesehatan fisik yang lebih baik, dan hubungan sosial yang kuat. Sedangkan karyawan dengan keterikatan kerja yang rendah melaporkan memiliki jam kerja yang terlalu banyak dan mengalami ketidakberdayaan psikologis serta putus asa dengan pekerjaan mereka (Attridge, 2009). Studi yang dilakukan di UK oleh Attridge (2009) menemukan bahwa keterikatan kerja berhubungan dengan jabatan pekerjaan yang lebih tinggi, pelatihan profesional, masa bekerja yang lebih rendah, dan tidak ada pengalaman traumatis dalam pekerjaan. Komunikasi yang efektif antara pihak manajemen dan karyawan menciptakan keterikatan yang lebih besar bagi karyawan (Attridge, 2009).

Keterikatan kerja terdiri dari tiga dimensi, yaitu (a) vigor, (b) dedication atau dedikasi, dan (c) absorption atau keterserapan (Schaufeli dan Bakker, 2004). Masingmasing dari ketiga dimensi tersebut mewakili komponen-komponen tertentu dalam keterikatan kerja. Vigor merupakan komponen fisik, dedication merupakan komponen emosional, dan absorption merupakan komponen kognitif dari keterikatan kerja (Attridge, 2009). Vigor dikarakteristikan dengan energi dan resiliensi mental yang tinggi saat bekerja, kemauan untuk menginvestasikan usaha kepada dirinya sendiri, dan persistensi dalam menghadapi kesulitan (Schaufelli, Bakker, Salanova; 2006). Dedication adalah perasaan yang dimiliki oleh seseorang mengenai signifikansi, antusiasme, inspirasi, kebanggaan, dan tantangan (Schaufelli, Bakker, Salanova; 2006). Absorption merujuk 
kepada keadaan seseorang yang berkonsentrasi dengan tinggi dan asyik dalam bekerja sehingga waktu terasa berlalu dengan cepat dan sulit untuk berhenti bekerja (Schaufelli, Bakker, Salanova; 2006).

Bakker dan Demerouti (dalam Bakker, 2009) menyebutkan dua dorongan utama yang menjadi sumber dari keterikatan kerja, yaitu: (a) sumber daya pekerjaan atau job resources, dan (b) sumber daya pribadi atau personal resources. Sumber daya pekerjaan adalah aspek fisik, sosial, dan organisasional dari sebuah pekerjaan. Sumber daya pekerjaan yang dapat mendorong munculnya keterikatan kerja bersifat: (a) mengurangi tuntutan kerja, (b) berfungsi dalam mencapai tujuan pekerjaan, (c) merangsang pertumbuhan diri, pembelajaran, dan perkembangan. Dukungan sosial dari rekan kerja dan atasan, umpan balik, otonomi, dan kesempatan belajar merupakan contoh-contoh dari sumber daya pekerjaan yang mampu mendorong keterikatan kerja dari karyawan (Bakker dan Demerouti dalam Bakker, 2009). Sumber daya pribadi merupakan karakteristik pribadi yang berhubungan dengan keterikatan kerja. Penelitian dari Langelaan et al (dalam Bakker, 2009) menghasilkan temuan bahwa pekerja yang memiliki keterikatan kerja memiliki mobilitas yang tinggi, neuroticism yang rendah, dan ekstraversi yang tinggi. Tipe kepribadian conscientciousness, emotional stability, dan extraversion dapat memprediksi keterikatan kerja (Mostert dan Rothmann dalam Bakker, 2009). Penelitian yang dilakukan oleh Adekola (2011) menemukan bahwa kebutuhan akan prestasi dan perilaku bekerja workaholic dapat menjadi prediktor dari keterikatan kerja.

\section{METODE PENELITIAN}

Rancangan penelitian ini merupakan penelitian kuantitatif dengan teknik analisis regresi. Subjek penelitian dalam penelitian ini diambil dari populasi karyawan yang bekerja di Universitas "X", dengan sampel sebanyak 105 orang karyawan. Peneliti memilih untuk melakukan penelitian di Universitas X karena berdasarkan hasil kuesioner evaluasi pelayanan dari karyawan Universitas X kepada mahasiswa, diperoleh hasil bahwa mahasiswa kurang merasa puas dnegna pelayanan dari karyawan Universitas $\mathrm{X}$, khususnya biro akademik. Subjek penelitian tidak termasuk dosen, cleaning service, dan petugas keamanan. Subjek penelitian diambil dengan menggunakan metode non-random sampling, dengan teknik convenient sampling. 
Vol. 9 No. 1 April 2016

PSIBERNETIKA

Alat ukur gaya kepemimpinan transformasional dan transaksional terdiri dari 57 butir yang disusun berdasarkan konstruk Bass \& Riggio (2006). Alat ukur tersebut akan diisi oleh karyawan, guna mengetahui persepsi karyawan terhadap gaya kepemimpinan atasan langsungnya. Selain itu, subjek penelitian juga mengisi alat ukur keterikatan kerja terdiri dari 17 butir yang disusun oleh Rostiana. Untuk menguji dan menganalisis data penelitian ini menggunakan teknik analisa regresi dengan bantuan program SPSS for windows.

\section{E. HASIL}

\section{Gambaran Gaya Kepemimpinan Transformasional Karyawan Universitas $\mathbf{X}$}

Variabel gaya kepemimpinan transformasional terdiri dari 5 dimensi, yaitu (a) attribute charisma, (b) intellectual stimulation, (c) individual consideration, (d) inspirational motivation, dan (e) idealized influence. Data yang diperoleh oleh peneliti adalah penilaian karyawan mengenai gaya kepemimpinan transformasional dari atasannya. Gambaran data dimensi-dimensi dari variabel gaya kepemimpinan transaksional menggunakan skala 1-4 dengan mean hipotesis alat ukur 2,5. Gambaran data dimensi attribute charisma memiliki skor mean empiris adalah 3,1254. Skor mean empiris lebih besar daripada skor mean hipotetis, maka disimpulkan bahwa karyawan institusi X menilai atasannya memiliki karakteristik attribute charisma yang tergolong tinggi. Gambaran data dimensi intellectual stimulation memiliki skor empiris sebesar 3,0895. Skor mean empiris dimensi intellectual stimulation lebih besar daripada skor mean hipotetis, sehingga dapat disimpulkan bahwa karyawan institusi $\mathrm{X}$ mempersepsikan atasannya memiliki karakteristik attribute charisma yang tergolong tinggi.

Pada dimensi selanjutnya, yaitu individualized consideration, skor mean empiris yang dihasilkan adalah 2,6918. Skor mean hipotesisnya adalah 2,5; maka skor mean empiris dimensi individualized consideration lebih tinggi daripada skor mean hipotesis. Berdasarkan data tersebut, peneliti menyimpulkan bahwa karyawan institusi X menilai atasannya memiliki karakteristik individualized consideration yang tergolong tinggi. Gambaran data dimensi inspirational motivation memiliki skor mean empiris 3,1320; lebih besar daripada skor mean hipotetis yaitu 2,5. Data ini menunjukkan bahwa karyawan institusi X menilai atasannya memiliki karakteristik inspirational motivation yang tergolong tinggi. Pada dimensi terakhir, idealized influence, menghasilkan skor mean 
empiris sebesar 3,1619. Skor ini berada di atas skor mean hipotetis, sehingga peneliti menyimpulkan bahwa karyawan institusi $\mathrm{X}$ mempersepsikan atasannya memiliki karakteristik idealized influence yang tergolong tinggi. Berdasarkan data-data di atas, dapat disimpulkan bahwa pada penelitian ini subyek memiliki skor mean empiris yang paling tinggi pada dimensi idealized influence, yaitu 3,1619. Secara umum, gambaran dimensi-dimensi pada variabel gaya kepemimpinan transformasional dapat dilihat pada tabel di bawah ini.

Tabel 1. Gambaran Dimensi dan Total Variabel Gaya Kepemimpinan Transformasional

\begin{tabular}{ccccc}
\hline $\begin{array}{c}\text { Dimensi Gaya Kepemimpinan } \\
\text { Transformasional }\end{array}$ & Minimum & $\begin{array}{c}\text { Maksi- } \\
\text { mum }\end{array}$ & $\begin{array}{c}\text { Mean } \\
\text { Empiris }\end{array}$ & $\begin{array}{c}\text { Standar } \\
\text { Deviasi }\end{array}$ \\
\hline $\begin{array}{c}\text { Attribute Charisma } \\
\text { Intellectual Stimulation }\end{array}$ & 2,33 & 4 & 3,1254 & 0,35715 \\
Individual Consideration & 2,20 & 4 & 2,6198 & 0,42060 \\
Inspirational Motivation & 2 & 3,43 & 2,6918 & 0,25124 \\
$\quad$ Idealized Influence & 2,17 & 4 & 3,1320 & 0,34238 \\
Total Gaya Kepemimpinan & 2,33 & 4 & 3,1619 & 0,42205 \\
Transformasional & & & 3,1328 & 0,27706 \\
\hline
\end{tabular}

\section{Gambaran Gaya Kepemimpinan Transaksional Karyawan Universitas X}

Variabel gaya kepemimpinan transaksional terdiri dari 3 dimensi, yaitu: (1) contingent reward, (2) active management by exception, dan (3) passive management by exception. Data yang diperoleh oleh peneliti adalah penilaian karyawan mengenai gaya kepemimpinan transaksional dari atasannya. Gambaran data dimensi-dimensi dari variabel gaya kepemimpinan transaksional menggunakan skala 1-4 dengan mean hipotesis alat ukur 2,5. Gambaran data dimensi contingent reward menunjukkan skor mean empiris sebesar 2,9921. Skor mean empiris pada dimensi contingent reward lebih besar daripada skor mean hipotetis, maka karyawan institusi X menilai atasannya memiliki karakteristik contingent reward yang tergolong tinggi. Gambaran data dimensi active management by exception menunjukkan skor mean empiris sebesar 3,0762; lebih besar dari skor mean hipotetisnya yaitu 2,5. Dari data tersebut, peneliti menyimpulkan bahwa karyawan institusi $\mathrm{X}$ mempersepsikan atasannya memiliki karakteristik active management by exception yang tergolong tinggi. Gambaran data dimensi passive management by exception 
Vol. 9 No. 1 April 2016

PSIBERNETIKA

menunjukkan skor mean empiris sebesar 2,6413; hal ini menunjukkan bahwa karyawan institusi X menilai atasannya memiliki karakteristik passive management by exception yang tergolong tinggi. Berdasarkan data-data di atas, dapat disimpulkan bahwa pada penelitian ini subyek memiliki skor mean empiris yang paling tinggi pada dimensi active management by exception, yaitu 3,0762. Secara umum, gambaran dimensi-dimensi pada variabel gaya kepemimpinan transaksional dapat dilihat pada tabel 2.

Tabel 2. Gambaran Dimensi dan Total Variabel Gaya Kepemimpinan Transaksional

\begin{tabular}{ccccc}
\hline $\begin{array}{c}\text { Dimensi Gaya Kepemimpinan } \\
\text { Transaksional }\end{array}$ & Minimum & $\begin{array}{c}\text { Maksi- } \\
\text { mum }\end{array}$ & $\begin{array}{c}\text { Mean } \\
\text { Empiris }\end{array}$ & $\begin{array}{c}\text { Standar } \\
\text { Deviasi }\end{array}$ \\
\hline $\begin{array}{c}\text { Contingent Reward } \\
\text { Active Management by Exception }\end{array}$ & 1,67 & 4 & 2,9921 & 0,36572 \\
$\begin{array}{c}\text { Passive Management by Exception } \\
\text { Total Gaya Kepemimpinan }\end{array}$ & 1 & 4 & 3,0762 & 0,45820 \\
Transaksional & 2,25 & 3,67 & 2,6413 & 0,70816 \\
\hline
\end{tabular}

\section{Gambaran Keterikatan Kerja}

Variabel keterikatan kerja terdiri dari 3 dimensi, yaitu: (1) vigor, (2) dedication, dan (3)absorption. Gambaran data dimensi-dimensi dari variabel keterikatan kerja menggunakan skala 1-6 dengan mean hipotesis alat ukur 3,5. Gambaran data dimensi vigor menunjukkan skor mean empiris sebesar 4,9492. Skor mean empiris pada dimensi vigor lebih besar daripada skor mean hipotetis, maka karyawan institusi $\mathrm{X}$ memiliki vigor yang tergolong tinggi. Gambaran data dimensi dedication menunjukkan skor mean empiris sebesar 4,9238; lebih besar dari skor mean hipotetisnya yaitu 2,5. Dari data tersebut, peneliti menyimpulkan bahwa karyawan institusi $\mathrm{X}$ memiliki dedication yang tergolong tinggi. Gambaran data dimensi absorption menunjukkan skor mean empiris sebesar 5,1429; hal ini menunjukkan bahwa karyawan institusi X memiliki absorption yang tergolong tinggi. Berdasarkan data-data di atas, dapat disimpulkan bahwa pada penelitian ini subyek memiliki skor mean empiris yang paling tinggi pada dimensi absorption, yaitu 5,1429. Secara umum, gambaran dimensi-dimensi pada variabel keterikatan kerja dapat dilihat pada tabel di bawah ini. 
Tabel 3. Gambaran Dimensi dan Total Variabel Keterikatan Kerja

\begin{tabular}{ccccc}
\hline Dimensi Keterikatan Kerja & Minimum & $\begin{array}{c}\text { Maksi- } \\
\text { mum }\end{array}$ & $\begin{array}{c}\text { Mean } \\
\text { Empiris }\end{array}$ & $\begin{array}{c}\text { Standar } \\
\text { Deviasi }\end{array}$ \\
\hline Vigor & 3,5 & 6 & 4,9492 & 0,52508 \\
Dedication & 3 & 6 & 4,9238 & 0,58070 \\
Absorption & 3 & 6 & 5,1429 & 0,79878 \\
Total Keterikatan Kerja & 3,54 & 5,92 & 4,9692 & 0,50573 \\
\hline
\end{tabular}

\section{Peran Interaksi Gaya Kepemimpinan Transformasional dan Transaksional terhadap Keterikatan Kerja}

Nilai signifikansi (p) dari kedua variabel bebas yang saling berinteraksi, yaitu gaya kepemimpinan transformasional dan gaya kepemimpinan transaksional, terhadap keterikatan kerja adalah 0 . Nilai signifikansi berada di bawah 0,01 ( $\mathrm{p}<0,01)$, oleh karena itu H0 ditolak dan H1 diterima. Data tersebut menunjukkan bahwa gaya kepemimpinan transformasional dan transaksional merupakan prediktor terhadap keterikatan kerja secara signifikan.

Nilai $\mathrm{R}$ square pada hasil uji multiple regression adalah 0,297 . Hal ini berarti sumbangan gaya kepemimpinan transformasional dan gaya kepemimpinan transaksional sebesar 29,7\%; sedangkan 70,3\% sisanya ditentukan oleh faktor lain.

\section{Peran Gaya Kepemimpinan Transformasional terhadap Keterikatan Kerja}

Berdasarkan hasil uji regresi, data menunjukkan bahwa skor signifikansi pada variabel gaya kepemimpinan transformasional adalah $0(\mathrm{p}<0,01)$; maka H0 ditolak dan H1 diterima. Hal ini berarti gaya kepemimpinan transformasional dapat memprediksi keterikatan kerja secara signifikan.

Nilai R square pada hasil uji regresi adalah 0,282 ( $\mathrm{R}$ square $=0,282$ ), hal ini berarti gaya kepemimpinan transformasional menjadi prediktor dengan bobot sebesar $28,2 \%$ terhadap keterikatan kerja, sedangkan sisanya $(71,8 \%)$ adalah faktor lain. 
Vol. 9 No. 1 April 2016

PSIBERNETIKA

\section{Peran Gaya Kepemimpinan Transaksional Terhadap Keterikatan Kerja}

Berdasarkan hasil uji regresi, data menunjukkan bahwa skor signifikansi pada variabel gaya kepemimpinan transaksional adalah 0,002 ( $<<0,01)$; maka H0 ditolak dan H1 diterima. Hal ini berarti gaya kepemimpinan transaksional dapat memprediksi keterikatan kerja secara signifikan.

Nilai $R$ square pada hasil uji regresi adalah 0,09 ( $\mathrm{R}$ square $=0,09)$, hal ini berarti persepsi gaya kepemimpinan transaksional memberikan sumbangan sebesar $9 \%$ terhadap keterikatan kerja, sedangkan sisanya (91\%) dipengaruhi oleh faktor lain.

\section{F. PEMBAHASAN}

Berdasarkan hasil regresi, peran gaya kepemimpinan transformasional dalam memprediksi keterikatan kerja memiliki nilai signfikansi $0(\mathrm{p}<0,01)$ yang berarti H0 ditolak, sehingga peneliti menyimpulkan bahwa gaya kepemimpinan transformasional mampu memprediksi keterikatan kerja secara signifikan. Nilai R square yang dihasilkan pada data adalah 0,282. Berdasarkan hasil tersebut, peneliti menyimpulkan bahwa persepsi gaya kepemimpinan transformasional memberikan sumbangan prediksi sebanyak $28,2 \%$ kepada keterikatan kerja dan 71,8\% sisanya dipengaruhi oleh faktor lain.

Temuan bahwa persepsi gaya kepemimpinan transformasional dapat memprediksi keterikatan kerja mendukung temuan Koppula (2008) bahwa gaya kepemimpinan transformasional berhubungan dengan keterikatan kerja. Gaya kepemimpinan transformasional merupakan gaya kepemimpinan yang mendukung perkembangan dan pertumbuhan karyawan, hal ini sesuai dengan pernyataan dari Sweetman dan Luthans (2010) bahwa keterikatan kerja dipengaruhi oleh sumber daya pekerjaan yang mampu meningkatkan pertumbuhan dan perkembangan karyawan. Dari temuan ini dapat dipahami bahwa ketika seorang pemimpin mampu menginspirasi karyawannya untuk mencapai tujuan bersama, serta menciptakan suasana kerja yang mendukung kemajuan dari para karyawannya, maka diprediksi dapat memunculkan keterikatan kerja pada karyawan.

Berdasarkan hasil regresi, prediksi gaya kepemimpinan transaksional terhadap keterikatan kerja memiliki nilai signifikansi 0,002 ( $\mathrm{p}<0,02)$ yang berarti H0 ditolak, sehingga peneliti menyimpulkan bahwa persepsi gaya kepemimpinan transaksional dapat memprediksi keterikatan kerja secara signifikan. Nilai R square yang dihasilkan oleh hasil 
analisis adalah 0,09. Berdasarkan hasil tersebut, peneliti menyimpulkan bahwa persepsi gaya kepemimpinan transaksional memberikan sumbangan prediksi sebanyak $9 \%$ kepada keterikatan kerja dan $91 \%$ sisanya dipengaruhi oleh faktor lain.

Gaya kepemimpinan transaksional mengandung unsur contingent reward yang berupa pemberian penghargaan atau hadiah kepada bawahannya bila dapat mengerjakan tugas dengan memuaskan (Bass \& Riggio, 2006). Hal ini berarti, pemimpin dengan gaya kepemimpinan transaksional akan mengakui prestasi dari karyawannya yang sudah bekerja dengan baik. Berdasarkan hasil analisis regresi yang didapatkan, gaya kepemimpinan transaksional dapat memprediksi keterikatan kerja. Hal ini selaras dengan penelitian dari Adekola (2011) bahwa kebutuhan akan prestasi dapat menjadi prediktor dari keterikatan kerja. Gaya kepemimpinan transaksional dapat memenuhi kebutuhan dari prestasi tersebut, karena sifatnya yang mengakui dan menghargai kinerja karyawan yang memuaskan. Temuan ini memberikan pemahaman bahwa gaya kepemimpinan yang menghargai prestasi karyawan dan memberikan apresiasi terhadap pencapaian tersebut dapat memprediksi keterikatan kerja dari karyawan-karyawannya.

Berdasarkan hasil yang diperoleh dari analisis data utama, maka hipotesis penelitian diterima, yaitu gaya kepemimpinan transformasional dan transaksional dapat memprediksi keterikatan kerja. Nilai signifikansi yang didapatkan melalui analisis multiple-regression adalah $\mathrm{p}=0<0,01$; dengan nilai $\mathrm{R}$ square 0,292 yang berarti interaksi gaya kepemimpinan transformasional dan transaksional memberikan sumbangan prediksi sebesar 29,2\% terhadap keterikatan kerja. Interaksi dari gaya kepemimpinan transformasional dan transaksional tidak hanya meningkatkan pertumbuhan dan perkembangan karyawan, namun juga memberikan penghargaan atau mengakui prestasi yang sudah dicapai oleh karyawan, sehingga peran dari gaya kepemimpinan transformasional yang mampu memprediksi keterikatan kerja diperkuat lagi dengan gaya kepemimpinan transaksional.

\section{G. SIMPULAN}

Simpulan dalam penelitian ini adalah baik gaya persepsi transformasional, transaksional, maupun interaksi antara keduanya dapat memprediksi keterikatan kerja karyawan yang bekerja di Universitas X. Interaksi antara kedua gaya kepemimpinan 
Vol. 9 No. 1 April 2016

PSIBERNETIKA

tersebut menjadi prediktor yang paling tinggi terhadap keterikatan kerja karyawan, disusul oleh gaya kepemimpinan transformasional. Gaya kepemimpinan transaksional sendiri juga dapat memprediksi keterikatan kerja, meskipun tidak sebaik interaksi gaya kepemimpinan transformasional-transaksional atau gaya kepemimpinan transformasional saja.

\section{H. SARAN}

Pada penelitian ini, ditemukan bahwa interaksi dari gaya kepemimpinan transformasional dan transaksional dapat memprediksi keterikatan kerja. Peneliti menyarankan untuk penelitian selanjutnya, dapat diteliti peran gaya kepemimpinan transformasional dan transaksional kepada variabel-variabel lainnya, terutama yang memiliki korelasi dengan keterikatan kerja seperti kepuasan kerja dan organizational citizenship behavior. Lalu juga dapat dibandingkan pengaruhnya antara kedua gaya kepemimpinan tersebut yang saling berinteraksi dibandingkan dengan persepsi satu gaya kepemimpinan saja.

Berkaitan dengan keterikatan kerja, peneliti juga menyarankan untuk mencari faktorfaktor lain yang dapat dilakukan oleh pemimpin/perusahaan guna meningkatkan keterikatan kerja karyawannya; seperti hasil dari penelitian ini bahwa persepsi gaya kepemimpinan transformasional dan transaksional berperan sebesar 29,7\% kepada keterikatan kerja dan masih ada 70,3\% faktor lain di luar penelitian ini. Selain itu, disarankan juga agar melakukan penelitian dengan variabel yang sama, namun pada konteksi organisasi yang berbeda, misalnya pada yayasan kesehatan, organisasi masyarakat, atau perusahaan pada industri tertentu, agar bisa mendapatkan perbandingan peran dari tiap gaya kepemimpinan terhadap keterikatan kerja karyawannya.

Berdasarkan hasil penelitian ini, saran yang dapat diberikan kepada perusahaan adalah seorang pemimpin hendaknya dapat menerapkan gaya kepemimpinan transformasional dan transaksional dalam memimpin kelompoknya sehingga dapat meningkatkan keterikatan kerja dari pengikutnya. Menerapkan gaya kepemimpinan transformasional dan transaksional lebih baik dibandingkan hanya menerapkan gaya kepemimpinan transformasional saja ataupun hanya menerapkan gaya kepemimpinan transaksional saja, dalam kaitannya untuk meningkatkan keterikatan kerja dari pengikutnya. 


\section{DAFTAR PUSTAKA}

Attridge, M. (2009). Measuring and managing employee work engagement: A review of the research and business literature. Journal of Workplace Behavioral Health, 24(4), 383-398.

Adekola, B. (2011). Antecedents and consequences of work engagement among managers and professionals in Nigeria. British Journal of Management \& Economics, 1(2), 8399.

Babcock-Roberson, M. E., \& Strickland, O. J. (2010). The relationship between charismatic leadership, work engagement, and organizational citizenship behaviors. The Journal of Psychology, 144(3), 313-326.

Bakker, A. B. (2009). Building engagement in the workplace. Dalam R. J. Burke \& C. L. Cooper (Eds.), The Peak Performing Organization (hal. 50-72). Oxon: Routlegde.

Bakker, A. B., Hakanen, J. J. Demerouti, E., \& Xanthopoulou, D. (2007). Job resources boost work engagement, particularly when job demands are high. Journal of Educational Psychology, 99(2), 274-284.

Bakker, A. B., Schaufeli, W. B., Leiter, M. P., \& Taris, T. W. (2008). Work engagement: an emerging concept in occupational health psychology. Work \& Stress, 22(3), 187200.

Bass, B.M., Avolio, B. J., Jung, D. I., \& Berson, Y. (2003). Predicting unit performance by assessing transformational dan transactional leadership. Journal of Applied Psychology, 88(2), 207-218.

Bass, B. M., \& Riggio, R. E. (2006). Transformational leadership (2nd ed.). NK: Lawrence Erlbaum Associates.

Chaplin, J.P. (2006). Kamus lengkap psikologi (K. Kartono, Penerj.) Jakarta: Raja Grafindo Perkasa. (Dipublikasikan pertama kali pada tahun 1985).

Goethals, G.R. (2005). Theories of presidential leadership. Annual Review of Psychology, 56, 545-570.

Hamstra, M. R. W., Yperen, N. W. V., Wisse B., \& Sassenberg, K. (2011). Transformational-transactional leadership and followers' regulatory focus. Journal of Personnel Psychology, 10(4), 182-186.

Kalargyrou, V., Pescosolido, A. T., \& Kalargiros, E. A. (2012). Leadership skills in management education. Academy of Educational Leadership Journal, 16(4), 39-63.

Koppula, R. (2008). Examining the relationship between transformational leadership and engagement. Master Theses, San Jose State University. 
Vol. 9 No. 1 April 2016

PSIBERNETIKA

Landy, F. J. \& Conte, J. M. (2007). Work in the 21st century: an introduction to industrial and organizational psychology. NY: McGraw-Hill.

Morrison, R. S., Jones, L., \& Fuller, B. (1997). The relation between leadership style and empowerment on job satisfaction of nurses. Journal of Nursing Administration. 27(5), 27-34.

Phipps, S.T.A, \& Prieto, L.C. (2011). The influence of personality factors on transformational leadership: Exploring the moderating role of political skill. International Journal of Leadership Studies, 6(3), 430-447.

Onorato, M. (2013). Transformational leadership style in the educational sector. Academy of Educational Leadership Journal, 17(1), 33-47.

Rothmann, S. (2008). Job satisfaction, occupational stress, burnout and work engagement as components of work-related wellbeing. SA Journal of Industrial Psychology, 34(3), $11-16$.

Schaufeli, W., \& Bakker, A. (2004). Utrecht work engagement scale: Preliminary manual. Utrecht University: Occupational Health Psychology Unit.

Schaufeli, W. B., Bakker, A. B., \& Salanova, M. (2006). The measurement of work engagement with a short questionnaire. Educational and Psychological Measurement, 66(4), 701-716.

Schaufeli, W.B. \& Salanova, M. (2007). Work engagement: an emerging psychological concept and its implications for organizations. Dalam S.W. Gilliland, D.D. Steiner \& D.P. Skarlicki (Eds.), Research in Social Issues in Management: Vol. 5. Managing Social and Ethical Issues in Organizations. Greenwich, CT: Information Age Publishers.

Sofyandi, H., \& Garniwa, I. (2007). Perilaku organisasional. Yogyakarta: Graha Ilmu.

Utami, I. T. (2010). Pengaruh gaya kepemimpinan transformasional terhadap motivasi kerja karyawan pada PT. Trade Servistama Indonesia-Tangerang. Budi Luhur Economics Journal, 5(1), 73-81. 